\title{
Malonates in Cyclocondensation Reactions
}

\section{Wolfgang Stadlbauer*, El-Sayed Badawey, Gerhard Hojas, Peter Roschger and Thomas Kappe}

Department of Chemistry, Organic Synthesis Group, Karl-Franzens-University Graz, Heinrichstrasse 28, A-8010 Graz, Austria/Europe. Tel. ++49 316380 5334, Fax ++49 3169840

* Author to whom correspondence should be addressed; e-mail wolfgang.stadlbauer@uni-graz.at, website: http://www-ang.uni-graz.at/ stadlbau.

Received: 21 December 2000; in revised form 7 March 2001 / Accepted: 8 March 2001 / Published: 31 March 2001

\begin{abstract}
The use of malonates such as diethyl malonates 9, (chlorocarbonyl)ketenes 15 and bis(2,4,6-trichlorophenyl) malonates $\mathbf{1 8}$ as reagents for cyclocondensation with 1,3dinucleophiles to give six-membered heterocycles is described. Further attempts to use malonates such as bis(trimethylsilyl) malonates $\mathbf{1 9}$ and bis(carbamimidoyl) malonates $\mathbf{2 9}$ as new cyclocondensation agents are described .
\end{abstract}

Keywords: ethyl malonates, (chlorocarbonyl)ketenes, bis(2,4,6-trichlorophenyl) malonates, bis(trimethylsilyl) malonates, sixmembered heterocycles.

\section{Introduction}

2-Substituted malonic acid derivatives are known to be very useful reagents in the field of Organic Synthesis. Besides the preparation of simple derivatives such as malonates or malonamides, malonic acid derivatives 1 react by cyclocondensation with dinucleophiles such as 2 to afford 5-, 6- and 7membered rings and thus give a variety of so-called "malonyl heterocycles" which possess as structural element a 1,3-dicarbonyl moiety $\mathbf{3}$ or its enolized tautomeric 1-oxo-3-hydroxy form 4 (Scheme 1). 


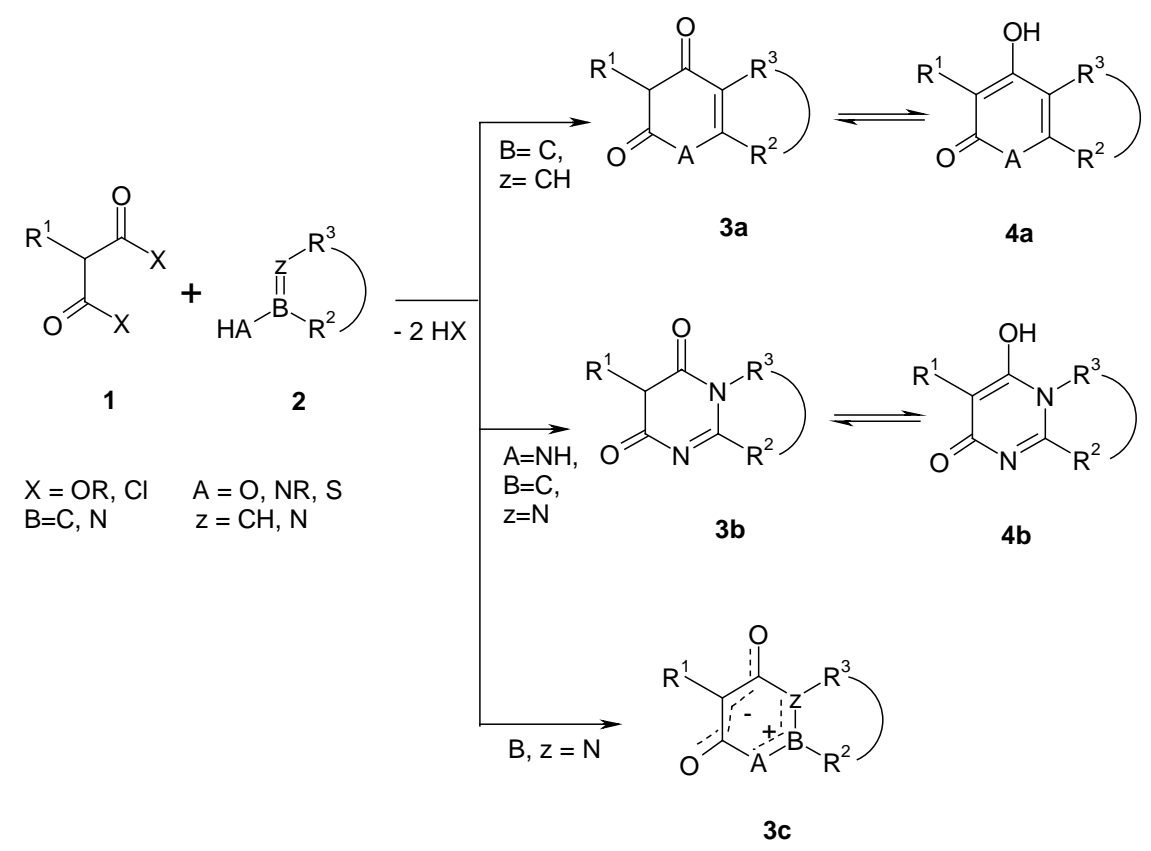

Scheme 1

Rather unreactive malonyl derivatives such as 2-substituted diethyl malonates react at elevated temperatures or in the presence of basic catalysts with sufficient reactive 1,3-dinucleophiles such as amidines and amides. The classical reactions of this type are the well-known syntheses of barbituric acids $\mathbf{6}$ [1] from malonates $\mathbf{5}$ and urea, and Tschitschibabin's synthesis of "malonyl- $\alpha$-aminopyridine", pyrido[1,2-a]pyrimidine-2,4-dione 7 [2] from diethyl malonate $5\left(\mathrm{R}^{1}=\mathrm{H}\right)$ and 2-aminopyridine (Scheme 2).
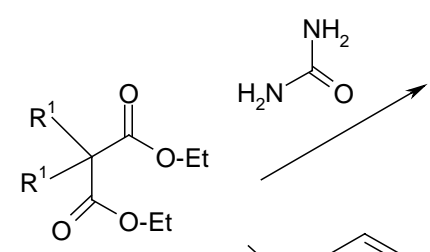

5<smiles>[R]C1([2H])CNC(=O)NC1=O</smiles><smiles></smiles><smiles>O=C1CC(=O)N2C=CC=CC2=N1</smiles>

7

\section{Scheme 2}

The first part of this paper (Schemes 3-7) briefly reviews cyclocondensations with reaction paths which are already known. As examples, reaction products are described, which are either new or have not been obtained earlier in the method reported in this paper. The second part (Schemes 8-10) 
describes our attempts to introduce new cyclocondensation agents such as bis-silyl malonates, bissuccinimidyl- and bis-carbamimidoyl malonates.

\section{Results and Discussion}

Pyrones and benzoanalogous coumarins $(\mathbf{1 1}, \mathrm{X}=\mathrm{O})$ have been obtained from enols or phenols $(\mathbf{8}$, $\mathrm{X}=\mathrm{O}$ ) and 2-unsubstituted or 2-monosubstituted diethyl malonates (9), e.g. ref. [3, 4]. Pyridones and benzoanalogous quinolones $(\mathbf{1 1}, \mathrm{X}=\mathrm{NR})$ have been obtained from azomethines or anilines $(\mathbf{8}, \mathrm{X}=$ NR) and malonates (9), e.g. ref. [4, 5]. As an example procedure the synthesis of 4-hydroxy-7methoxy-3-(4-methoxyphenyl)-coumarin (11a, $\mathrm{R}^{2}-\mathrm{R}^{3}=-\mathrm{CH}=\mathrm{C}(\mathrm{OMe})-\mathrm{CH}=\mathrm{CH}-, \mathrm{X}=\mathrm{O}, \mathrm{R}^{1}=4-\mathrm{MeO}-$ $\left.\mathrm{C}_{6} \mathrm{H}_{4}\right)$ from diethyl 2-(4-methoxyphenyl)malonate $\left(\mathbf{9 a}, \mathrm{R}^{1}=4-\mathrm{MeO}-\mathrm{C}_{6} \mathrm{H}_{4}\right)$ and 2-methoxyphenol (8a, $\left.\mathrm{R}^{2}-\mathrm{R}^{3}=-\mathrm{CH}=\mathrm{C}(\mathrm{OMe})-\mathrm{CH}=\mathrm{CH}-, \mathrm{X}=\mathrm{O}\right)$ is described in the experimental part (Scheme 3).

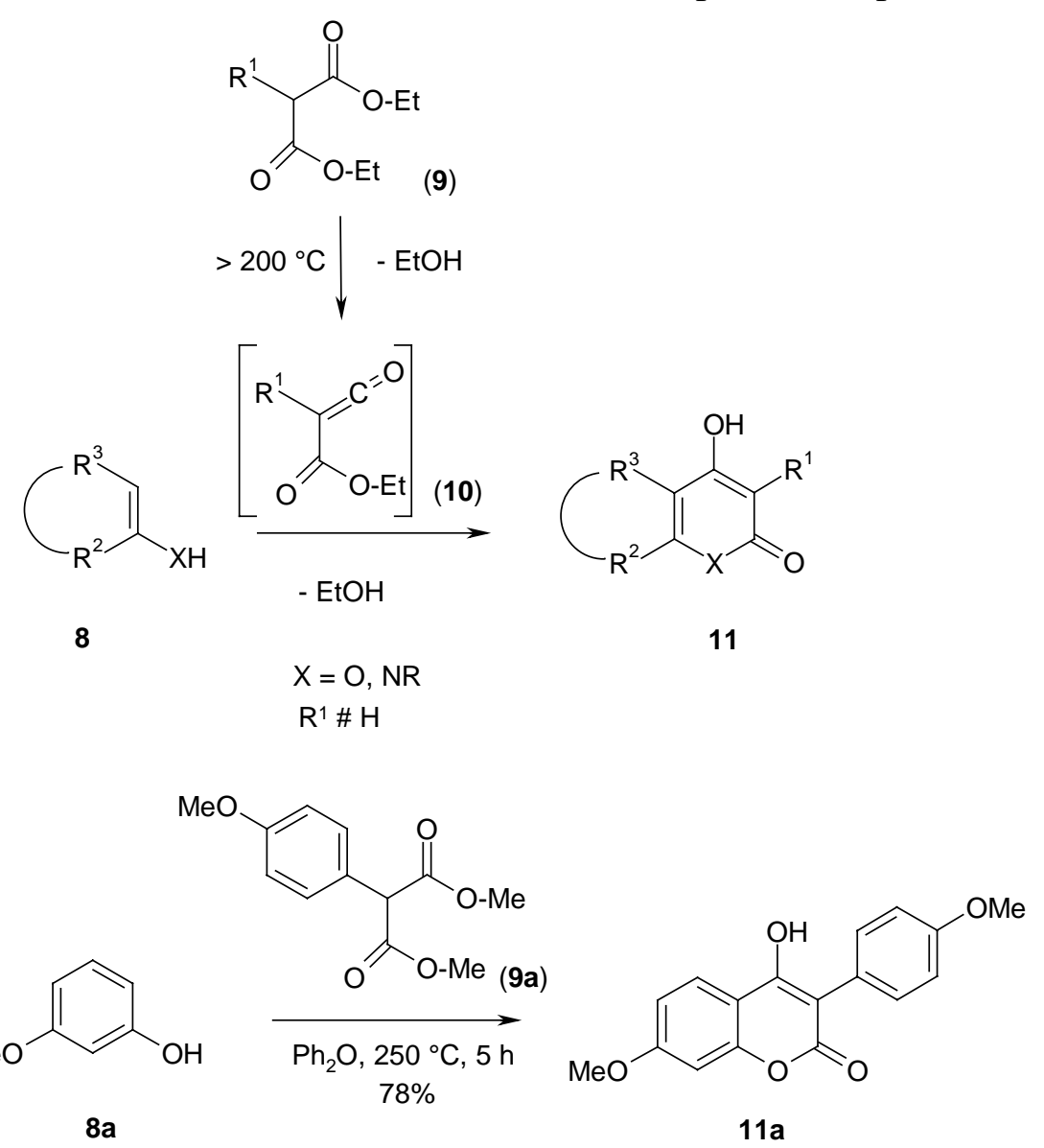

Scheme 3

Reported procedures for compounds of type 11 involve multistep procedures (see e.g. ref. [6], which describes the reaction of $\mathbf{8 a}$ with bis(2,4,6-trichlorophenyl) 2-(4-methoxyphenyl)malonate 18, $\left.\mathrm{R}^{1}=4-\mathrm{MeO}-\mathrm{C}_{6} \mathrm{H}_{4}\right)$. We were able to show that especially 2-arylmalonates $9\left(\mathrm{R}^{1}=\mathrm{Ph}\right)$ provide at reaction temperatures above $250^{\circ} \mathrm{C}$ good synthons for simple and quick cyclization reactions in good to moderate yields [5] (probably via arylketene ester intermediates 10, $\mathrm{R}^{1}=\mathrm{Ph}$ [7]). The only disadvantage of this reaction sequence is its high reaction temperature, which prevents its use for sensitive substrates and substituents. The ketene mechanism is also supported by observations obtained 
during the reaction: at temperatures below $200^{\circ} \mathrm{C}$ the first mole of alcohol is observed to be liberated when the open chain ester or amide is formed, then it needs a temperature of more than $250^{\circ} \mathrm{C}$ to liberate the second mole of alcohol and to form the ketene intermediate 10. Thermal investigations of the thermolysis reaction of the phenol 8a and the malonate 9a by differential scanning calorimetry (DSC) show, that at about $160^{\circ} \mathrm{C}$ a first exothermic reaction starts immediately after the endothermic boiling point of the phenol 8a (in accordance with findings during the formation of malonamides), then a weak exothermic reaction begins at about $240^{\circ} \mathrm{C}$ followed by a strong exothermic reaction (onset $260^{\circ} \mathrm{C}$ ). These data are in accordance with the observations obtained from the synthetic experiments as described above.

Malonic acid derivatives $\mathbf{1 2}$ are not reactive enough to react with dinucleophiles $\mathbf{8}$. However, when they are converted in situ with phosphoryl chloride [8] to the corresponding acid chlorides, they give pyrones and pyridones 11 with dinucleophiles $\mathbf{8}$. As an example procedure the one step synthesis of 4hydroxy-1-phenyl-2-quinolone (11b) from malonic acid $\left(\mathbf{1 2 b}, \mathrm{R}^{1}=\mathrm{H}\right)$, phosphoryl chloride and diphenylamine $\left(\mathbf{8 b}, \mathrm{R}^{2}-\mathrm{R}^{3}=-\mathrm{CH}=\mathrm{CH}-\mathrm{CH}=\mathrm{CH}=, \mathrm{X}=\mathrm{N}-\mathrm{Ph}\right)$ is described. The reported synthesis of 12b involves a 3-step procedure from malonates $9\left(R^{1}=H\right)$ [3]. Although the yields are rather low (30$50 \%$ ), the quick and short pathway overcomes this disadvantage (Scheme 4).<smiles>[Y]C1=C[R]CCCP1</smiles>

8<smiles>c1ccc(Nc2ccccc2)cc1</smiles>

$8 b$

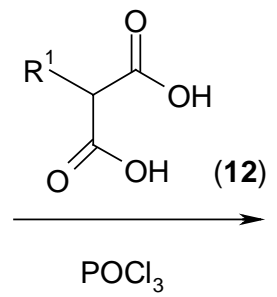

$\mathrm{X}=\mathrm{O}, \mathrm{NR}$

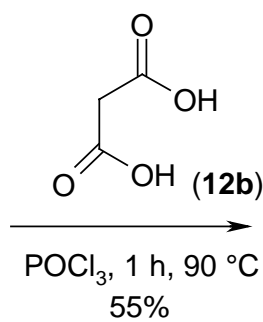

Scheme 4<smiles>[X]c1cc([R])c([R])c(O)c1[R]</smiles>

11<smiles>O=c1cc(O)c2ccccc2n1-c1ccccc1</smiles>

$11 b$

Less reactive or sensitive substrates of type $\mathbf{2}$ require more reactive malonyl derivatives. Malonyl dichlorides $\mathbf{1 4}$ already react at lower temperatures in aprotic solvents with dinucleophiles $\mathbf{1 3}$ to give heterocycles 16 [9]. Above $80^{\circ} \mathrm{C}$, malonyl dichlorides lose hydrogen chloride to form chlorocarbonyl ketenes $\mathbf{1 5}$, which are more reactive than malonyl dichlorides $\mathbf{1 4}$ and react in the presence of bases such as triethylamine with many substrates at room temperature [10]. As an example procedure, the improved synthesis of 5-benzyl-2,3-diphenyl-6H-6-oxo-1,3-oxazin-3-ium-4-olate (16a, $\mathrm{A}=\mathrm{O}, \mathrm{B}=\mathrm{C}$, $\mathrm{z}=\mathrm{N}, \mathrm{R}^{1}=\mathrm{CH}_{2} \mathrm{Ph}, \mathrm{R}^{2}=\mathrm{R}^{3}=\mathrm{Ph}$ ), having a mesoionic betaine structure, is described (Scheme 5). 
Attempts to obtain 16a with other less reactive malonates gave only rearrangement products because of the high temperature which was necessary for the cyclocondensation [11].

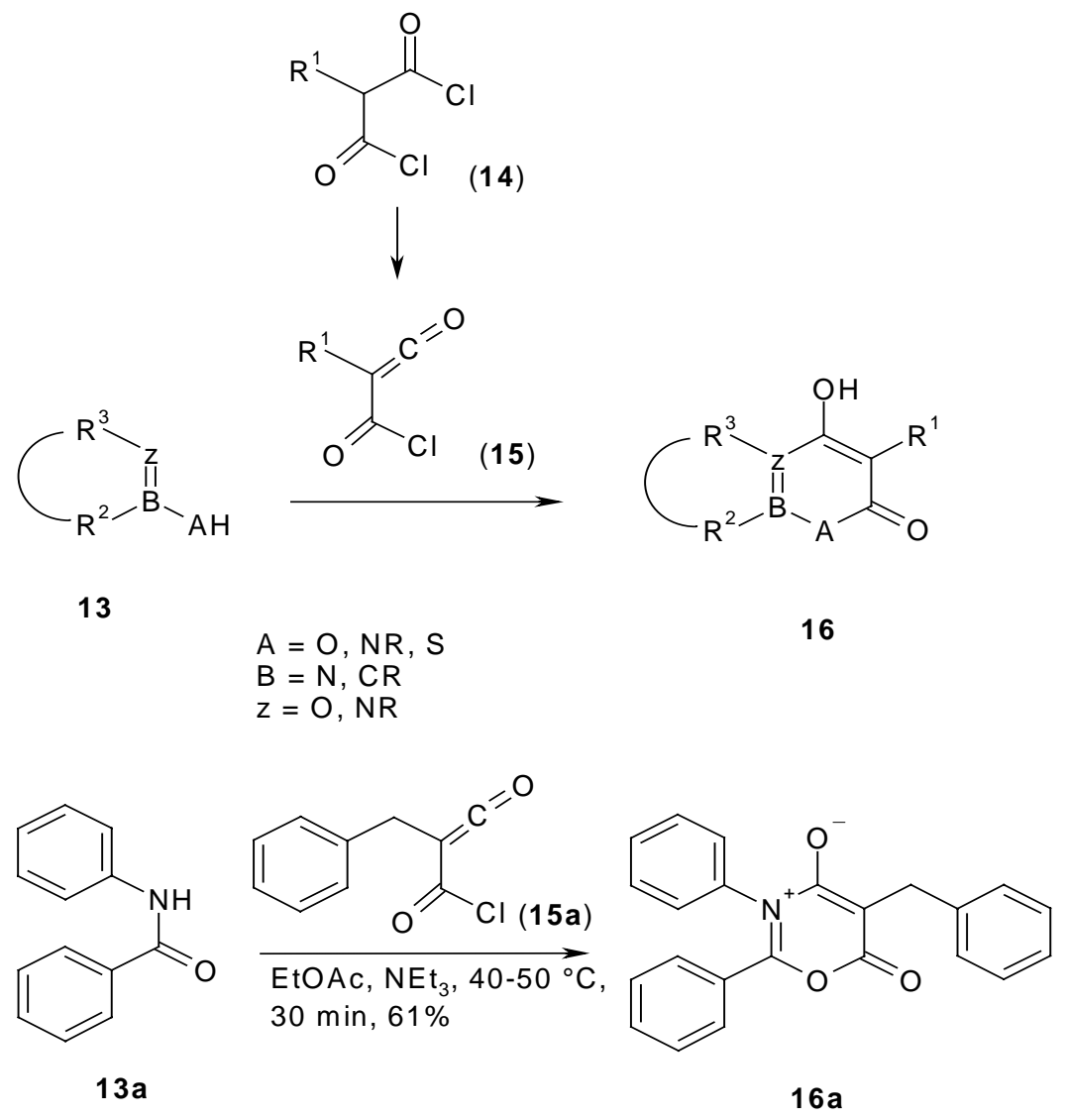

\section{Scheme 5}

The most electrophilic malonic acid derivative has been found in carbon suboxide 17 [12], which reacts with dinucleophiles 13 at low temperatures $\left(-78^{\circ} \mathrm{C}\right)$ to give five- or six-membered malonyl heterocycles 16 (Scheme 6). Its preparation is performed either by pyrolysis of diacetyl tartaric anhydride, or from malonic acid $\mathbf{1 2 b}$ and phosphorus pentoxide, or from bis(trimethylsilyl) malonate 19b and phosphorus pentoxide [12].<smiles>O=C(O)CC(=O)O</smiles>

$$
\Delta \mathrm{T} \downarrow-2 \mathrm{H}_{2} \mathrm{O}
$$

$\mathrm{O}=\mathrm{C}=\mathrm{C}=\mathrm{C}=\mathrm{O}$<smiles>P/C=P\CCCCP</smiles>

13
(17)

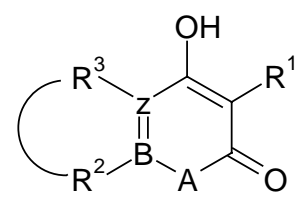

Scheme 6
16 
A large number of 1,3-dinucleophiles $\mathbf{1 3}$ has been reacted with bis(2,4,6-trichlorophenyl) malonates $\mathbf{1 8}$ (obtained from malonic acids 12 and 2,4,6-trichlorophenol) leading to six-membered malonyl heterocycles [13]. Most of these condensations have been carried out thermally by fusion of $\mathbf{1 3}$ and $\mathbf{1 8}$ at $150-250^{\circ} \mathrm{C}$ in the melt; in some cases bromobenzene or diphenylether have been used as solvent. $\mathrm{N}, \mathrm{N}$-dinucleophiles $\mathbf{1 3}(\mathrm{A}=\mathrm{z}=\mathrm{NR})$ can also be reacted at room temperature. As an example procedure, the synthesis of 5-benzyl-4-hydroxy-8,9,10,11-tetrahydro-pyrido[3,2,1:jk]carbazol-6-one (16b) at $250{ }^{\circ} \mathrm{C}$ is described, which yields $16 \mathbf{b}$ in about $30 \%$ yield (Scheme 7 ). The reported synthesis uses bis(2,4-dichlorophenyl) malonate [23], which is avoided nowadays because of synthetic and health problems. Experiments with diethyl malonates 9 give only yields below $5 \%$.
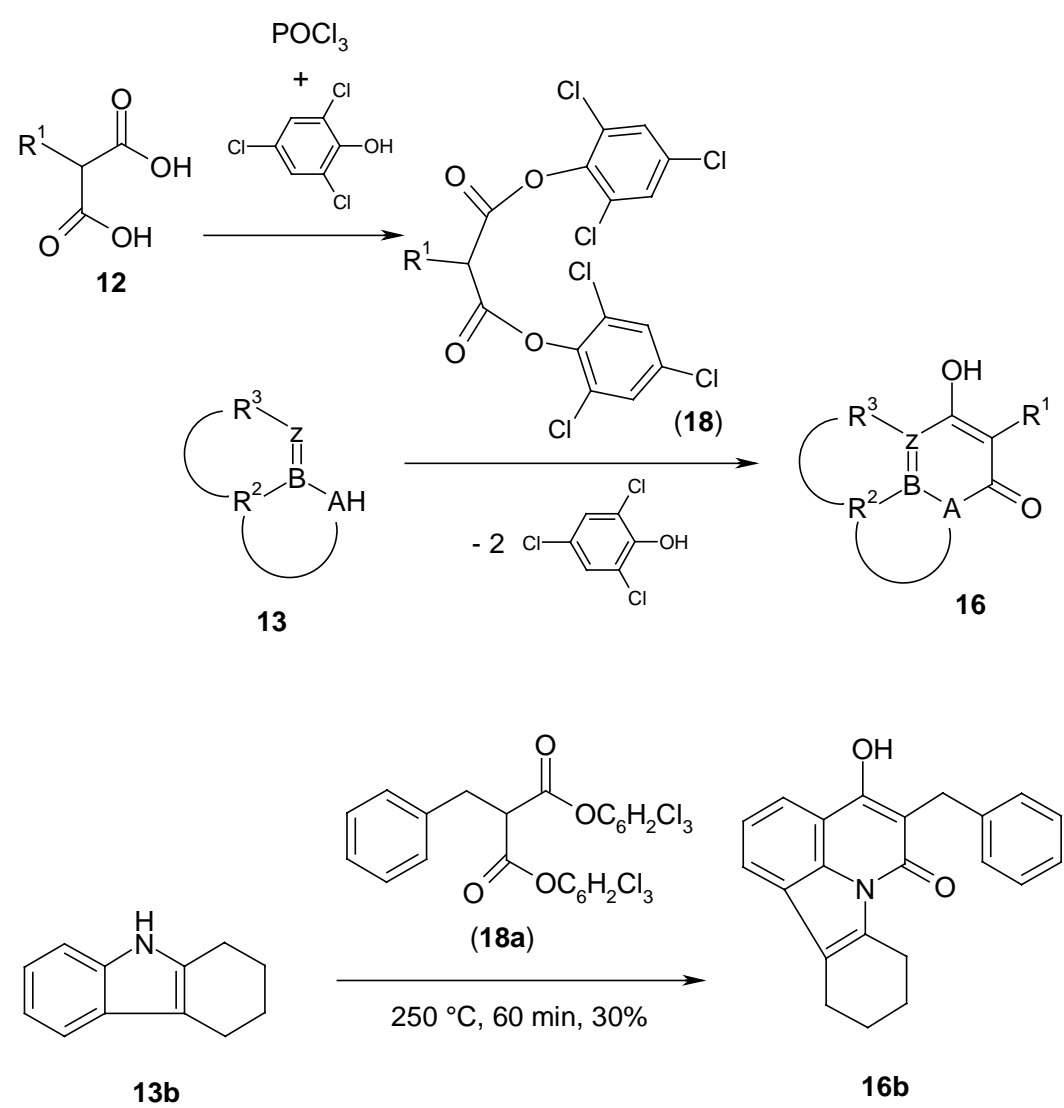

Scheme 7

The reactive malonate reagents, malonyl dichlorides 14, carbon suboxide 17 and bis(2,4,6trichlorophenyl) malonates $\mathbf{1 8}$ are very valuable reagents, but they are expensive and can be stored only for a limited time without decomposition. Another aspect is that malonyl dichlorides $\mathbf{1 4}$ and bis(2,4,6-trichlorophenyl) malonates 18 contain chlorine, an element of ill repute in Green Chemistry. Consequently we made several attempts to replace these reagents with other reactive derivatives without such disadvantages.

For this reason we have tried to prepare a new generation of reactive malonates such as trimethylsilyl malonates and mixed anhydrides of malonates. As test substrates we have used aromatic amines which have only weak basic nitrogens, with which suitably reactive malonates should readily form malondianilides $\mathbf{2 0}$ or cyclization products at low temperatures. 
Bis(trimethylsilyl) malonates $\mathbf{1 9}$ have been prepared according to a reported method [14], by reacting the appropriate malonic acid 12 with trimethylsilyl chloride in the presence of pyridine. The spectroscopic data of $\mathbf{1 9}$ confirmed their structure. The known reaction of anilines with substituted diethyl malonates 9 gives malondianilides at temperatures below $200^{\circ} \mathrm{C}$, and 4-hydroxyquinolones such as $\mathbf{1 1 b}$ are obtained at higher temperatures (Scheme 4). With bis(trimethylsilyl) 2-ethylmalonate 19b, a reaction occured at similar temperatures as observed with malonates 9 , but the products were 2ethyl-N,N'-diphenylmalondiamide 20, obtained as a minor byproduct, together with butyranilide $\mathbf{2 1}$, which is formed from 19b after a desilylation and decarboxylation step. 2-Cyanomethylbenzimidazole 22 was used as 1,3-dinucleophilic substrate for cyclocondensation with bis(trimethylsilyl) malonates 19. According to a previous investigation [15] the dinucleophile 22 reacts readily with reactive bis(2,4,6-trichlorophenyl) malonates 18 in refluxing bromobenzene at $150^{\circ} \mathrm{C}$ to give pyrido[1,2a]benzimidazoles. The reaction of bis(trimethylsilyl) malonates 19 in refluxing bromobenzene, however, gave only C-acylation to yield 2-(2,3-dihydro-1H-benzimidazol-2-yliden)-3-oxoalkanenitriles 23 without cyclization to the nitrogen (Scheme 8). Thus our experiments revealed that bis(trimethylsilyl) malonates 19 are no substitutes for reactive malonyl reagents 14, 15, 17 and 18 . Their reactivity for synthetic purposes is too small and decomposition takes place already at rather low reaction temperatures.
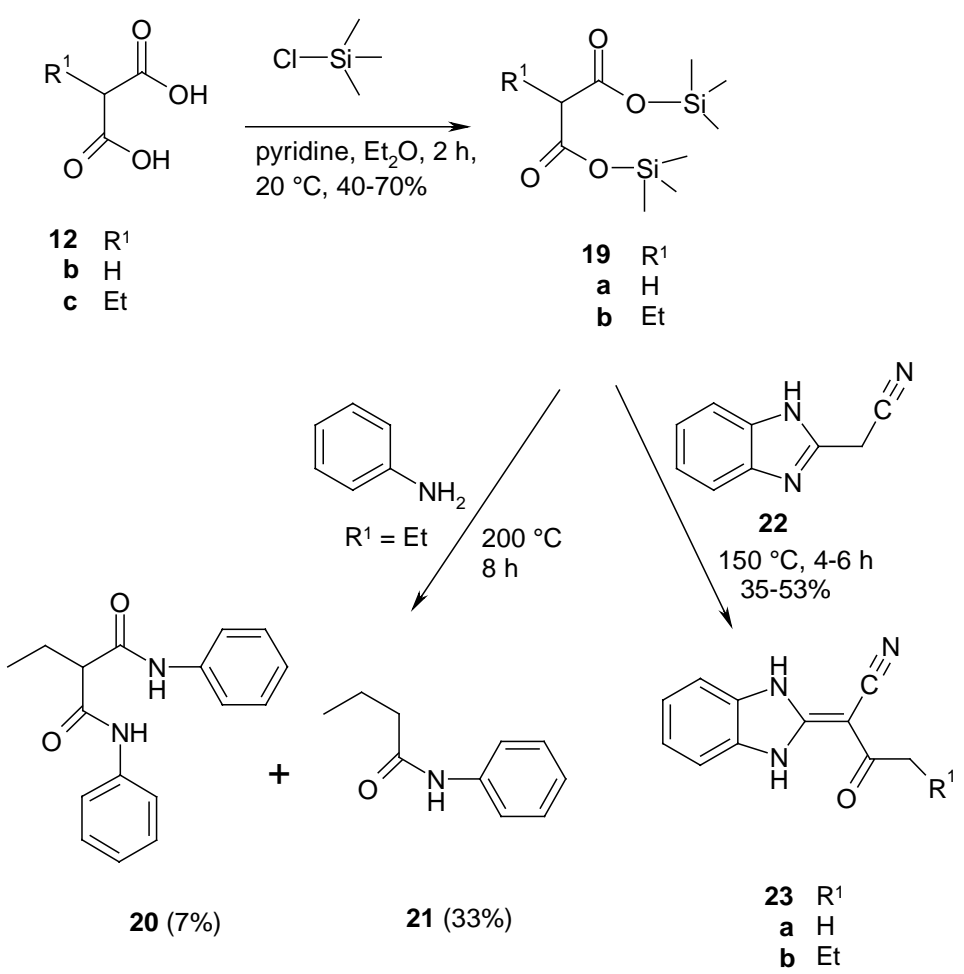

\section{Scheme 8}

Mixed anhydrides of malonic acid $\left(\mathbf{1 2}, \mathrm{R}^{1}=\mathrm{H}\right)$ with acetic acid have been used as in situ reagents for reactive 1,3-dinucleophiles, however, the scope of this reaction has been found to be limited to a small number of 1,3-dinucleophiles such as ureas [1]. With acetophenonaniles 24 the intermediate 4hydroxypyridones 25 formed react with excess malonic acid $\left(\mathbf{1 2}, \mathrm{R}^{1}=\mathrm{H}\right)$ to give pyrono- 
pyridinediones 26. As an example, the synthesis of 4-hydroxy-6,7-diphenyl-pyrano[3,2-c]pyridine2,5(6H)-dione (26a, $\left.\mathrm{R}^{2}=\mathrm{H}\right)$ is described. In order to obtain a more versatile reactive anhydride reagent, we tried to synthesize a mixed anhydride 27 of malonic acid and carbonic acid by reaction of malonic acids 12 with ethyl chloroformate in the presence of triethylamine at $0-5^{\circ} \mathrm{C}$ in dichloromethane using a standard procedure for benzoyl malonates [16]. However, only 2-substituted diethyl malonates 9 have been isolated, a result which is similar to the findings reported for the mixed anhydrides of the half ester of malonic acids [17] (Scheme 9).

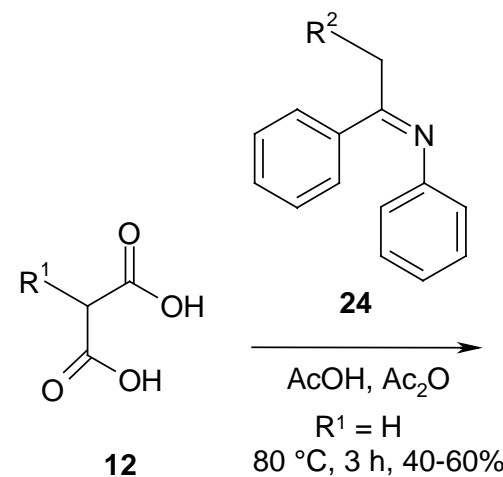

12<smiles>CCOC(=O)Cl</smiles><smiles>[R]C(C(=O)OCC)C(=O)OC(=O)OCC</smiles>

27<smiles>[R]C(C(=O)OCC)C(=O)OCC</smiles>

9<smiles>[Z]c1c(O)cc(=O)n(-c2ccccc2)c1-c1ccccc1</smiles>

25<smiles>O=C(O)CC(=O)O</smiles><smiles>[R]c1c(-c2ccccc2)n(-c2ccccc2)c(=O)c2c(O)cc(=O)oc12</smiles>

26

\section{Scheme 9}

The reaction of succinimidyl- and O-acylurea esters is a well-known and widely used method for acylations and condensations of carboxylic acids in peptide synthesis [18]. The preparation of succinimidyl esters is in general mediated by the activation with N,N'-diisopropylcarbodiimide [18], which should give as intermediate the bis(carbamimidoyl) malonates $\mathbf{2 9}$. Nucleophilic attack by $\mathrm{N}$ hydroxysuccinimide should give succinimidylates $\mathbf{2 8}$, and as byproduct N,N'-diisopropylurea. The 
succinimide-N-oxy group in succinimidylates is reported as a good leaving group in the reaction with nucleophiles [18].

The reaction of malonic acids $\mathbf{1 2}$ with $\mathrm{N}$-hydroxysuccinimide has been performed using a recently successfully applied reaction sequence for alkanoic acids [19]. We used this procedure and dissolved the appropriate malonic acid $\mathbf{1 2}$ in dry dichloromethane; then a small excess of N-hydroxysuccinimide was added, the solution was cooled and a small excess of $\mathrm{N}, \mathrm{N}$-diisopropylcarbodiimide was then added. After a reaction time of 24 hours, the reaction mixture contained a large number of compounds. The main product was N,N'-diisopropylurea, the other compounds were present in too small quantities and they have not been isolated. Other solvents such as diethylether decreased the number of compounds, however we were unable to isolate bis(succinimidoyl) malonates $\mathbf{2 8}$.

Similar reactive derivatives of carboxylic acids have been described in ref. [20]. We used the reported procedure and reacted 2-benzylmalonic acid (12a) with $\mathrm{N}, \mathrm{N}$ '-diisopropylcarbodiimide in diethylether at $0^{\circ} \mathrm{C}$ for 2 hours and then removed the solvent. The resulting oil contained one new main product, probably bis(carbamimidoyl) 2-benzylmalonate 29a as shown by NMR data, and some byproducts in minor quantities. The crude oil was not further purified and reacted with aniline as an example nucleophile in dioxane at room temperature. However, tlc analysis did not show any reaction, which means that at low temperatures no reaction takes place between 29a and aniline (Scheme 10). At higher temperatures only decomposition products have been observed.

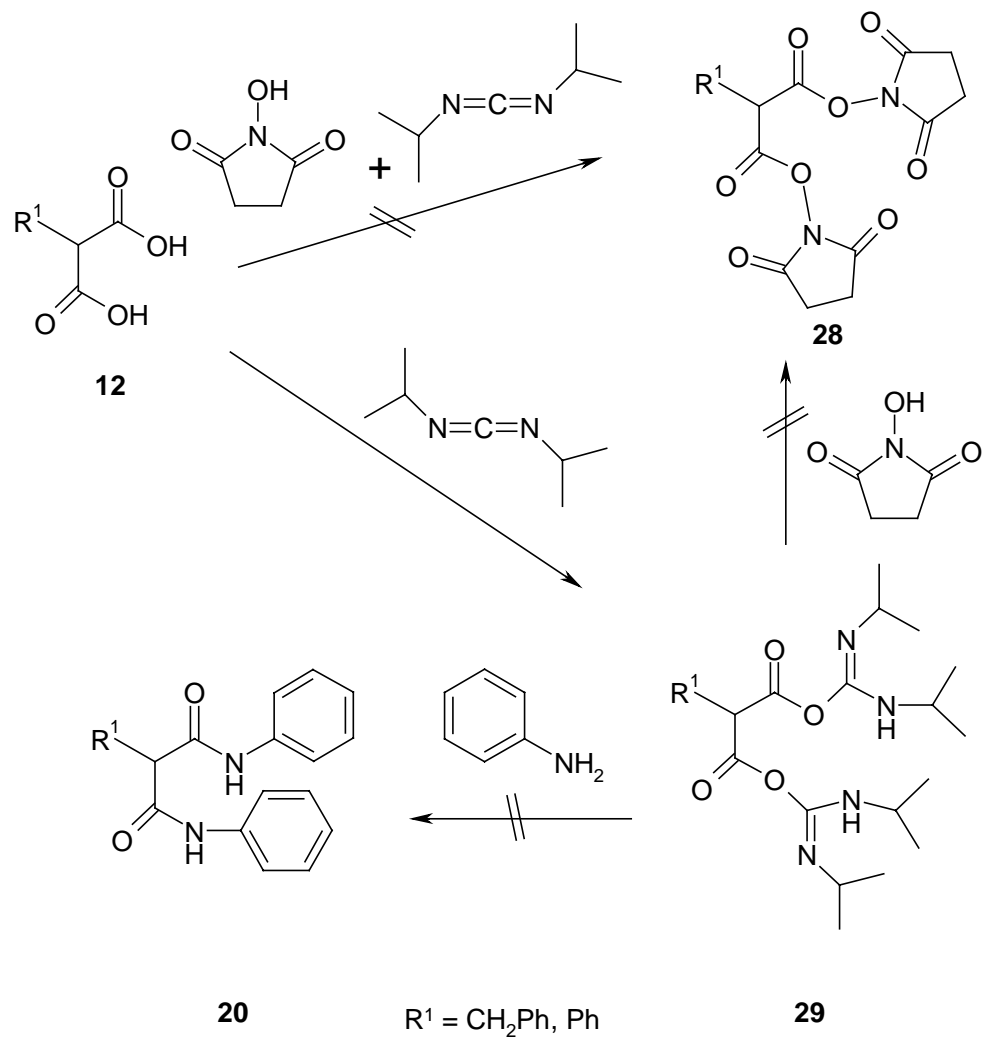

Scheme 10 


\section{Conclusions}

Derivatives of malonic acids have been shown to be versatile reagents, especially for the preparation of heterocyclic ring systems. In many cases the use of cheap and easy obtainable diethyl malonates 9 (Scheme 3) at high reaction temperatures has been shown to replace the more reactive malonyl dichlorides 14, (chlorocarbonyl)ketenes 15, carbon suboxide 17 and bis(2,4,6-trichlorophenyl) malonates 18 (Schemes 5-7). However, for sensitive and less reactive substrates these reactive derivatives 14, 15, 17 and 18 are of great importance. Experiments to substitute these reactive derivatives by silyl esters 19 (Scheme 8), mixed anhydrides 27 (Scheme 9), bis(succinimidoyl) malonates 28 (Scheme 10) or bis(carbamimidoyl) malonates 29 (Scheme 10) have been unsuccessful.

\section{Experimental}

\section{General}

Melting points were determined on a Gallenkamp Melting Point Apparatus, Mod. MFB-595 in open capillary tubes. Calorimetric data were obtained on a Rheometric Scientific DSC-Plus instrument equipped with V5.42 of the differential scanning calorimetry software. The differential scanning calorimetry plots were recorded between $25-400^{\circ} \mathrm{C}$, with a heating rate of $2-10^{\circ} \mathrm{C} / \mathrm{min}$, and $1.5-3 \mathrm{mg}$ compound in sealed aluminium crucibles (11 bar). The ${ }^{1} \mathrm{H}-\mathrm{NMR}$ spectra were recorded on a Varian Gemini 200 instrument (200 MHz) or a Bruker AM 360 instrument (360 MHz). The ${ }^{13} \mathrm{C}-\mathrm{NMR}$ spectra were recorded on a Bruker AM 360 instrument $(90 \mathrm{MHz})$. Chemical shifts are reported in ppm from internal tetramethylsilane standard and are given in $\delta$-units. Infrared spectra were taken on a PerkinElmer 298 spectrophotometer or a Galaxy Series FTIR 7000 in potassium bromide pellets. Elemental analyses were performed on a Fisons elemental analyzer, Mod. EA 1108 and are within \pm 0.4 of the theoretical percentages. Mass spectra were taken on a Finnigan 4000 (EI: $70 \mathrm{eV}, \mathrm{CI}: 120 \mathrm{eV}$, methane). All reactions were monitored by thin layer chromatography (tlc) carried out on $0.2 \mathrm{~mm}$ silica gel F-254 (Merck) plates using uv light (254 and $366 \mathrm{~nm}$ ) for detection. Common reagent-grade chemicals are either commercially available and were used without further purification or prepared by standard literature procedures.

\section{4-Hydroxy-7-methoxy-3-(4-methoxyphenyl)-coumarin (11a).}

A solution of dimethyl 2-(4-methoxyphenyl)malonate (9a) (23.8 g, $0.1 \mathrm{~mol})$ and 3-methoxyphenol (8a) $(12.4 \mathrm{~g}, 0.1 \mathrm{~mol})$ in diphenylether $(20 \mathrm{~g})$ was heated for $3 \mathrm{~h}$ to $200-250^{\circ} \mathrm{C}$ in a metal bath. During this time methanol (about $5 \mathrm{~mL}$ ) was liberated. When the liberation of methanol had stopped, the reaction mixture was heated to an oil bath temperature of $300^{\circ} \mathrm{C}$ for $2 \mathrm{~h}$; during this time further $4 \mathrm{~mL}$ of methanol was liberated. After cooling, the reaction mixture was diluted with toluene $(50 \mathrm{~mL})$, filtered by suction and washed with cyclohexane $(100 \mathrm{~mL})$. The yield was $24.3 \mathrm{~g}(78 \%)$, yellowish prisms, mp $220.1-220.3^{\circ} \mathrm{C}$ (ethanol); lit. mp. $215-217^{\circ} \mathrm{C}$ [6]. Spectral data are identical with the reported data in ref. [6]. Calorimetric data of the reaction mixture of $\mathbf{8 a}$ and $\mathbf{9 a}$ : b.p. onset $157.4^{\circ} \mathrm{C}$, 
peak maximum $160.1^{\circ} \mathrm{C}, \Delta \mathrm{H}=0.2 \mathrm{mcal} / \mathrm{mg}, 1$. reaction onset at $161.7^{\circ} \mathrm{C}$, peak maximum $172.6^{\circ} \mathrm{C}, \Delta \mathrm{H}$ $=-2.6 \mathrm{mcal} / \mathrm{mg}$, 2. reaction onset at $240.5^{\circ} \mathrm{C}$, peak maximum $267.2^{\circ} \mathrm{C}, \Delta \mathrm{H}=-2.3 \mathrm{mcal} / \mathrm{mg}$, 3. reaction onset at $281.5^{\circ} \mathrm{C}$, peak maximum $310.2^{\circ} \mathrm{C}, \Delta \mathrm{H}=-7.8 \mathrm{mcal} / \mathrm{mg}$.

4-Hydroxy-1-phenyl-2(1H)-quinolone (11b).

A suspension of diphenylamine $(\mathbf{8 b})(84.5 \mathrm{~g}, 0.5 \mathrm{~mol})$ and malonic acid (12b) (72.8 $\mathrm{g}, 0.7 \mathrm{~mol})$ in phosphoryl chloride $\left(183.6 \mathrm{~g}, 1.2 \mathrm{~mol}\right.$ ) was heated for $1 \mathrm{~h}$ to $90^{\circ} \mathrm{C}$. Then the mixture was poured into ice/water $(1 \mathrm{~L})$, the precipitate filtered, dissolved in $2 \mathrm{~N}$ sodium hydroxide solution and filtered again. The solution was acidified with $2 \mathrm{~N}$ hydrochloric acid, filtered by suction, washed with water and dried. The yield was $65.3 \mathrm{~g}$ (55\%), yellowish prisms, mp $293^{\circ} \mathrm{C}$ (lit. mp 294.5-295.5 ${ }^{\circ} \mathrm{C}$ [3]). Spectral data are identical with the reported data in ref. [3].

\section{5-Benzyl-2,3-diphenyl-6H-6-oxo-1,3-oxazin-3-ium-4-olate (16a).}

a) 2-Benzyl-2-(chlorocarbonyl)ketene (15a): To a stirred solution of 2-benzylmalonic acid (12a, $\left.\mathrm{R}^{1}=\mathrm{CH}_{2} \mathrm{Ph}\right)(39 \mathrm{~g}, 0.2 \mathrm{~mol})$ in toluene $(50 \mathrm{~mL})$, thionyl chloride $(59.5 \mathrm{~g}, 0.6 \mathrm{~mol})$ was added dropwise under a nitrogen atmosphere. The reaction mixture was heated under nitrogen for $24 \mathrm{~h}$ under reflux and then toluene and excess thionyl chloride was removed by distillation under reduced pressure $\left(60^{\circ} \mathrm{C}, 130 \mathrm{~mm} \mathrm{Hg}\right)$. The residue was purified by distillation under reduced pressure $\left(134-140^{\circ} \mathrm{C}, 15\right.$ $\mathrm{mm} \mathrm{Hg})$. The yield was $27.2 \mathrm{~g} \mathrm{(70 \% );} \mathrm{lit.} \mathrm{bp} 110-112^{\circ} \mathrm{C}(1.5 \mathrm{~mm} \mathrm{Hg})$ [21].

b) 5-Benzyl-2,3-diphenyl-6H-6-oxo-1,3-oxazin-3-ium-4-olate (16a): To a solution of benzanilide (13a) $(5.9 \mathrm{~g}, 0.03 \mathrm{~mol})$ in warm dry ethyl acetate $\left(150 \mathrm{~mL}, 40-50^{\circ} \mathrm{C}\right)$ 2-benzyl-2-(chlorocarbonyl)ketene (15a) $(6.5 \mathrm{~g}, 0.033 \mathrm{~mol})$ and dry triethylamine $(4.5 \mathrm{~mL})$ was added. The yellow reaction mixture turned red and viscous and a small amount of a dark solid precipitated. The reaction mixture was kept for $30 \mathrm{~min}$ at room temperature and then the precipitate was filtered off, the filtrate taken to dryness under reduced pressure and triturated with xylene. The resulting precipitate was filtered by suction and dried. The yield was $6.5 \mathrm{~g}(61 \%)$, yellow prisms, mp $160^{\circ} \mathrm{C}$. Lit. mp. $161^{\circ} \mathrm{C}$ [11]. Spectral data are identical with the reported data in ref. [11].

5-Benzyl-4-hydroxy-8,9,10,11-tetrahydro-pyrido[3,2,1:jk]carbazol-6-one (16b).

a) Bis(2,4,6-trichlorophenyl) 2-benzylmalonate (18a): A mixture of dry 2-benzylmalonic acid (12a, $\mathrm{R}^{1}=\mathrm{CH}_{2} \mathrm{Ph}$ ) (97.1 g, $0.5 \mathrm{~mol}$ ), 2,4,6-trichlorophenol (157.9 g, $0.8 \mathrm{~mol}$ ) and phosphorylchloride (161 $\mathrm{g}, 1.05 \mathrm{~mol}$ ) was heated under reflux until the evolution of $\mathrm{HCl}$ gas had stopped (about $6 \mathrm{~h}$ ). The reaction mixture was then poured onto crushed ice (1.5 1), filtered by suction, washed with ice-water, dissolved in toluene (1 L) and washed with 5\% sodium bicarbonate solution and water. After drying with sodium sulfate, the solvent was removed under reduced pressure. The residue was triturated with hexane, filtered and dried at room temperature in a desiccator. The yield was $111.4 \mathrm{~g}(50.4 \%)$, beige prisms, mp $104^{\circ} \mathrm{C}$ (lit. mp $106-107^{\circ} \mathrm{C}$ [22]). 
b) 5-Benzyl-4-hydroxy-8,9,10,11-tetrahydro-pyrido[3,2,1:jk]carbazol-6-one (16b): A mixture of 1,2,3,4-tetrahydrocarbazole (13b) (3.75 g, $22 \mathrm{mmol})$ and bis(2,4,6-trichlorophenyl) 2-benzylmalonate $\left(\mathbf{1 8 a}, \mathrm{R}^{1}=\mathrm{CH}_{2} \mathrm{Ph}\right)(12.1 \mathrm{~g}, 22 \mathrm{mmol})$ was heated without solvent for $60 \mathrm{~min}$ to $250^{\circ} \mathrm{C}$. The $2,4,6$ trichlorophenol vapors were removed via a funnel into the water pump. After cooling the dark reaction mixture was washed with hexane until the product became semi-solid. Then the product was stirred with $0.5 \mathrm{M}$ sodium hydroxide solution $(500 \mathrm{~mL})$ overnight, filtered, the filtrate extracted with toluene $(2 \times 100 \mathrm{~mL})$ and then the aqueous phase acidified with conc. hydrochloric acid. The precipitate was washed with water, recrystallized from glacial acetic acid/water and dried. The yield was $21.6 \mathrm{~g} \mathrm{(30 \% ),}$ $\mathrm{mp} 240^{\circ} \mathrm{C}$ dec. (from glacial acetic acid/water). Lit. [23] mp. $240-245^{\circ} \mathrm{C}$ (dec.; no yield given); IR: 3100-2900 m, $1670 \mathrm{~s}, 1640 \mathrm{sh}, 1610 \mathrm{~s}, 1545 \mathrm{~s} \mathrm{~cm}^{-1} ;{ }^{1} \mathrm{H}-\mathrm{NMR}$ (DMSO-d ${ }_{6}$ ): $\delta=1.80-1.95$ (t, J = $6 \mathrm{~Hz}, 4$ $\left.\mathrm{H}, 9-\mathrm{CH}_{2}, 10-\mathrm{CH}_{2}\right), 2.60\left(\mathrm{t}, \mathrm{J}=6 \mathrm{~Hz}, 2 \mathrm{H}, 11-\mathrm{CH}_{2}\right), 2.80\left(\mathrm{~m}, 2 \mathrm{H}, 8-\mathrm{CH}_{2}\right), 3.50$ (s, benzyl- $\left.\mathrm{CH}_{2}\right), 7.10-$ 7.60 (m, 6 H, 5 ArH, H-2), 7.70 (d, J = 6 Hz, 1 H, H-1), 8.00 (d, J = 6 Hz, 1 H, H-3), 11.1 (s, 1 H, OH).

Bis(trimethylsilyl) malonate $\left(\mathbf{1 9 a}, \mathrm{R}^{1}=\mathrm{H}\right)$.

Malonic acid (12b, $\left.\mathrm{R}^{1}=\mathrm{H}\right)(10.4 \mathrm{~g}, 100 \mathrm{mmol})$ was reacted according to the procedure described in ref. [14] with trimethylsilylchloride $(21.7 \mathrm{~g}, 200 \mathrm{mmol})$ and worked up as described. The yield was $20.0 \mathrm{~g}(81 \%)$, yellowish oil, bp $102^{\circ} \mathrm{C}(15 \mathrm{~mm} \mathrm{Hg})$; lit. bp: $97^{\circ} \mathrm{C}(12 \mathrm{~mm} \mathrm{Hg})$ [14]. IR: $2960 \mathrm{~s}, 1720 \mathrm{~s}$, $1410 \mathrm{w}, 1340 \mathrm{~m} \mathrm{~cm}^{-1}$; ${ }^{1} \mathrm{H}-\mathrm{NMR}\left(\mathrm{CDCl}_{3}\right): \delta=0.35(\mathrm{~s}, 18 \mathrm{H}, 6 \mathrm{Me}), 3.3\left(\mathrm{~s}, 2 \mathrm{H}, \mathrm{CH}_{2}\right)$. Analysis: for $\mathrm{C}_{9} \mathrm{H}_{20} \mathrm{O}_{4} \mathrm{Si}_{2}$ (248.43) Calcd. C 43.51, H 8.11; Found C 43.30, H 8.29

Bis(trimethylsilyl) 2-ethylmalonate $\left(\mathbf{1 9 b}, \mathrm{R}^{1}=\mathrm{Et}\right)$.

To a stirred suspension of 2-ethylmalonic acid (12c, $\left.\mathrm{R}^{1}=\mathrm{Et}\right)(13.2 \mathrm{~g}, 100 \mathrm{mmol})$ and pyridine (16 $\mathrm{mL}, 200 \mathrm{mmol})$ in dry diethylether $(150 \mathrm{~mL})$, trimethylsilylchloride $(21.7 \mathrm{~g}, 200 \mathrm{mmol})$ was added dropwise keeping the temperature at $0^{\circ} \mathrm{C}$. Then the reaction mixture was stirred at room temperature for $2 \mathrm{~h}$, hexane $(200 \mathrm{~mL})$ was added, and the separated salt was filtered off. The filtrate was distilled under reduced pressure $\left(105-115^{\circ} \mathrm{C}, 15 \mathrm{~mm} \mathrm{Hg}\right)$. The yield was $20.1 \mathrm{~g}(73 \%)$, yellowish oil, bp $112^{\circ} \mathrm{C}$ (20 mm Hg). IR: $2985 \mathrm{~s}, 1720 \mathrm{~s}, 1460 \mathrm{w}, 1350 \mathrm{~m} \mathrm{~cm}^{-1} ;{ }^{1} \mathrm{H}-\mathrm{NMR}\left(\mathrm{CDCl}_{3}\right): \delta=0.35(\mathrm{~s}, 18 \mathrm{H}, 6 \mathrm{Me})$, $1.0(\mathrm{t}, 3 \mathrm{H}, \mathrm{Me}), 1.9\left(\mathrm{~m}, 2 \mathrm{H}, \mathrm{CH}_{2}\right), 3.2(\mathrm{t}, 1 \mathrm{H}, \mathrm{CH})$; Analysis: for $\mathrm{C}_{11} \mathrm{H}_{24} \mathrm{O}_{4} \mathrm{Si}_{2}$ (276.48) Calcd. C 47.79, H 8.75; Found C 47.88, H 8.78

\section{2-Ethyl-N,N'-diphenylmalondiamide (20) and $N$-phenylbutanamide (21).}

A mixture of aniline $(0.93 \mathrm{~g}, 10 \mathrm{mmol})$ and bis(trimethylsilyl) 2-ethylmalonate $\left(\mathbf{1 9 b}, \mathrm{R}^{1}=\mathrm{Et}\right)(2.77$ $\mathrm{g}, 10 \mathrm{mmol}$ ) was heated in an oil bath at $200^{\circ} \mathrm{C}$ for $8 \mathrm{~h}$. After cooling to room temperature, the reaction mixture was digested with ethanol and cooled to $5^{\circ} \mathrm{C}$. The dianilide 20 precipitated and was filtered by suction. The yield of $\mathbf{2 0}$ was $0.2 \mathrm{~g}$ (7\%), colorless prisms, mp $216-219^{\circ} \mathrm{C}$ (ethanol); tlc and spectral data are identical with an authentic sample obtained from diethyl 2-ethylmalonate and aniline. The filtrate was concentrated to $5 \mathrm{~mL}$ under reduced pressure and the residue treated with hexane. The precipitate was filtered by suction to yield $0.5 \mathrm{~g}(31 \%)$ of $21, \mathrm{mp} 87-89^{\circ} \mathrm{C}$ (hexane); lit. mp. $91-92^{\circ} \mathrm{C}$ 
[25]; tlc and spectral data are identical with an authentic sample obtained from butanoic chloride and aniline.

2-(2,3-Dihydro-1H-benzimidazol-2-yliden)-3-oxobutanenitrile $\left(\mathbf{2 3 a}, \mathrm{R}^{1}=\mathrm{H}\right)$.

A solution of 2-cyanomethylbenzimidazole (22) $(1.57 \mathrm{~g}, 10 \mathrm{mmol})$ and bis(trimethylsilyl) malonate $\left(19 \mathrm{a}, \mathrm{R}^{1}=\mathrm{H}\right)(2.62 \mathrm{~g}, 10.6 \mathrm{mmol})$ was refluxed in bromobenzene $(50 \mathrm{~mL})$ for $4-6 \mathrm{~h}$ during which the product separated out. After cooling, the product was filtered and washed with benzene. The yield was $1.0 \mathrm{~g}(50 \%), \mathrm{mp}>350^{\circ} \mathrm{C}$ (dimethylformamide). IR: $3300-2500 \mathrm{~b}, \mathrm{~m}, 2220 \mathrm{~s}, 1620 \mathrm{w}, 1600 \mathrm{~s}, 1510 \mathrm{~m}$, $1470 \mathrm{w} \mathrm{cm}^{-1}$; ${ }^{1} \mathrm{H}-\mathrm{NMR}$ (DMSO-d D : $\delta=2.20$ (s, $3 \mathrm{H}, \mathrm{Me}$ ), 7.20 and 7.50 (2 dd, $\left.4 \mathrm{H}, \mathrm{ArH}\right), 13.1$ (s, $\mathrm{NH}$ ); Analysis: for $\mathrm{C}_{11} \mathrm{H}_{9} \mathrm{~N}_{3} \mathrm{O}$ (199.21) Calcd. C 66.32, H 4.55, N 21.09; Found C 65.97, H 4.66, N 20.86

2-(2,3-Dihydro-1H-benzimidazol-2-yliden)-3-oxohexanenitrile $\left(\mathbf{2 3 b}, \mathrm{R}^{1}=\mathrm{Et}\right)$.

A solution of 2-cyanomethylbenzimidazole (22) $(1.57 \mathrm{~g}, 10 \mathrm{mmol})$ and bis(trimethylsilyl) 2ethylmalonate $\left(\mathbf{1 9 b}, \mathrm{R}^{1}=\mathrm{Et}\right)(2.76 \mathrm{~g}, 10 \mathrm{mmol})$ was reacted and worked up as described for 23a. The yield was $0.8 \mathrm{~g}(35 \%), \mathrm{mp} 318-320^{\circ} \mathrm{C}$ (dimethylformamide). IR: 3600-2600 b, m, $2220 \mathrm{~s}, 1620 \mathrm{w}$, $1600 \mathrm{~s}, 1560 \mathrm{~s}, 1530 \mathrm{~s} \mathrm{~cm}^{-1}$; ${ }^{1} \mathrm{H}-\mathrm{NMR}\left(\mathrm{DMSO}_{6}\right)$ : $\delta=0.95$ (t, $\left.3 \mathrm{H}, \mathrm{Me}\right), 1.60\left(\mathrm{~m}, 2 \mathrm{H}, \mathrm{CH}_{2}\right), 2.45(\mathrm{t}, 2$ $\mathrm{H}, \mathrm{CH}_{2} \mathrm{CO}$ ), 7.20 and $7.50(2 \mathrm{dd}, \mathrm{J}=7 \mathrm{~Hz}, 4 \mathrm{H}, \mathrm{ArH}), 12.80(\mathrm{~s}, \mathrm{~b}, 2 \mathrm{NH}) ;{ }^{13} \mathrm{C}-\mathrm{NMR}\left(\mathrm{DMSO}-\mathrm{d}_{6}\right): \delta=$ $13.0(\mathrm{Me}), 18.0\left(\mathrm{CH}_{2}\right), 41.1\left(\mathrm{CH}_{2}\right), 64.5(=\mathrm{C}-\mathrm{CN}), 112.2(\mathrm{C} 5$ and $\mathrm{C}-6), 121.1(\mathrm{CN}), 123.2(\mathrm{C} 4$ and C7), 130.9 (C3a and C7a), 151.0 (C2 of benzimidazole), 192 (CO); Analysis: for $\mathrm{C}_{13} \mathrm{H}_{13} \mathrm{~N}_{3} \mathrm{O}(227.27)$ Calcd. C 68.71, H 5.77, N 18.49; Found C 68.23, H 5.32, N 18.40

4-Hydroxy-6,7-diphenyl-pyrano[3,2-c]pyridine-2,5(6H)dione $\left(\mathbf{2 6} \mathbf{a}, \mathrm{R}^{2}=\mathrm{H}\right)$.

A solution of malonic acid (12b, $\left.\mathrm{R}^{1}=\mathrm{H}\right)(104 \mathrm{~g}, 1 \mathrm{~mol}$, well dried over potassium hydroxide) in warm dry ethyl acetate $(800 \mathrm{~mL})$ was treated with acetic anhydride $(190 \mathrm{~mL}, 2.0 \mathrm{~mol})$ and N1,1diphenyl-1-ethanimine $\left(\mathbf{2 4 a}, \mathrm{R}^{2}=\mathrm{H}\right)(98.0 \mathrm{~g}, 0.5 \mathrm{~mol})$ and heated under reflux for $3 \mathrm{~h}$ by exclusion of moisture. Strong stirring is necessary because sometimes the reaction product precipitated which caused bumping of the boiling reaction mixture. After cooling the mixture was allowed to stand several hours for crystallization and was then filtered by suction. The precipitate was triturated with methanol $(300 \mathrm{~mL})$ for $3 \mathrm{~h}$ to remove impurities and filtered again to give a light yellow product which was pure enough for synthetic purposes. The yield was $71 \mathrm{~g}(43 \%)$, beige prisms, mp. 294-296 ${ }^{\circ} \mathrm{C}$ (DMF), lit. mp. $293-296^{\circ} \mathrm{C}[24]$.

Bis(carbamimidoyl) 2-benzylmalonate (29a).

To a solution of 2-benzylmalonic acid $\left(\mathbf{1 2 a}, \mathrm{R}^{1}=\mathrm{CH}_{2} \mathrm{Ph}\right)(1.95 \mathrm{~g}, 0.01 \mathrm{~mol})$ in diethylether (50 $\mathrm{mL})$ at $0^{\circ} \mathrm{C}, \mathrm{N}, \mathrm{N}^{\prime}$-diisopropylcarbodiimide $(2.52 \mathrm{~g}, 0.2 \mathrm{~mol})$ was added and stirred at this temperature for 2 hours. The solvent was removed i.vac. and the oily residue washed with hexane and dried. The 
yield was $4.2 \mathrm{~g}$ of a yellow oil, which contained one new main product (shown by tlc analysis) besides traces of 12a and N,N'-diisopropyl urea. The oil was used without further purification for reactions. ${ }^{1} \mathrm{H}-\mathrm{NMR}$ (DMSO- $\mathrm{d}_{6}$ ) of the crude product: $\delta=0.7-0.9$ (m, aliphatic $\mathrm{H}$, solvent), 1.1-1.4 (m, Me of $i$ propyl group), 3.1-3.3 (m, benzyl- $\mathrm{CH}_{2}$ ), 3.6-4.0 (m, $i$-propyl- $\mathrm{CH}$, malonyl- $\mathrm{CH}$ ), 7.1-7.4 (m, ArH), 8.8 $(\mathrm{m}, \mathrm{NH}, \mathrm{OH})$.

\section{References and Notes}

1. Biltz, H.; Witteck, H. Alkylated and acylated barbituric acids. Ber. Dtsch. Chem. Ges. 1921, 54, 1035-1059; Clark-Lewis, J. W., Thompson, M. J. Preparation of 1,3-dimethylbarbituric acid and formation of 5-ethoxycarbonylacetyl-1,3-dimethylbarbituric acid. J. Chem. Soc. 1959, 1628-1629.

2. Tschitschibabin, A. E. Formation of bicyclic derivatives of $\alpha$-aminopyridine. Ber. Dtsch. Chem. Ges. 1924, 57, 1168-1172.

3. Roschger, P.; Fiala, W.; Stadlbauer, W. Nucleophilic substitution and ringclosure reactions of 4chloro-3-nitroquinolones. J. Heterocycl. Chem. 1992, 29, 225-231.

4. Kappe, Th. The 'pyrono route' to 4-hydroxyquinolines and 4-hydroxy-2-pyridones. Il Farmaco 1999, 54, 309-315.

5. Kappe, Th.; Ajili, S.; Stadlbauer, W. Activated malonates as synthons for heterocycles. A new method for the preparation of 4-hydroxy-2(1H)-pyridones. J. Heterocycl. Chem. 1988, 25, 463468 .

6 Kappe, Th.; Brandner, A. A simple synthesis of coumestrol. Z. Naturforsch., Part B. 1974, 29, 292-293.

7 Ziegler, E. Syntheses of heterocycles. Österr. Chem. Ztg. 1958, 59, 155-159; Chimia 1970, 24, 62-64; Ziegler, E.; Sterk, H. Thermal formation of ketenes. Monatsh. Chem. 1968, 99, 1958-1961.

8 Ziegler, E.; Junek, H.; Nölken, E.; Gelfert, K.; Salvador, R. Fused heterocycles. Monatsh. Chem. 1961, 92, 814-819.

9 Ziegler, T. Malonyl chloride. In Encylopedia of Reagents for Organic Synthesis, Paquette, L. A., Ed.; John Wiley \& Sons, Chichester - New York - Brisbane - Toronto - Singapore, 1995; Vol. 3, 3217-3219.

10 Kappe, Th. (Chlorocarbonyl)ethylketene. In Encylopedia of Reagents for Organic Synthesis, Paquette, L. A., Ed.; John Wiley \& Sons, Chichester - New York - Brisbane - Toronto - Singapore, 1995; Vol. 2, 1098-1100.

11 Kappe, Th., Golser W., Hariri M., Stadlbauer W. Synthesis and reactions of mesoionic 1,3oxazines. Chem. Ber. 1979, 112, 1585-1594

12 Kappe, Th. Carbon suboxide. In Encylopedia of Reagents for Organic Synthesis, Paquette, L. A., Ed.; John Wiley \& Sons, Chichester - New York - Brisbane - Toronto - Singapore, 1995; Vol. 2, 996-997.

13 Kappe, Th. Bis(2,4,6-trichlorophenyl) malonate. In Encylopedia of Reagents for Organic Synthesis, Paquette, L. A., Ed.; John Wiley \& Sons, Chichester - New York - Brisbane - Toronto Singapore, 1995; Vol. 1, 577-579.

14 Schmidt, U., Schwochau, M. Syntheses with trimethylsilyl esters of acetoacetate and malonate. A new way to diacylmethanes and diacylacetates. Monatsh. Chem. 1967, 98, 1492-1511. 
15 Rida, S. M., Soliman, F. S. G., Badawey, E. A. M., El-Ghazzawi, E., Kader, O., Kappe, Th. Syntheses and biological investigations of some substituted pyrido[1,2-a]benzimidazoles. $J$. Heterocyclic Chem. 1988, 25, 1087-1093.

16 Price, J. A., Tarbell, D. S. Diethyl benzoylmalonate. Rabjohn, N., Ed. Organic Synth. 1963, Coll. Vol. 4, 286-288.

17 Gutman, A. L., Boltanski, A. A mild, rapid and convenient synthesis of half esters of malonic acid. Tetrahedron Lett. 1985, 26, 1573-1576.

18 Bodanszky, M., Bodanszky, A. The practice of peptide synthesis, p. 125. Springer, Berlin Heidelberg - New York 1994.

19 Daxecker, H., Raab, M. Solid phase peptide syntheses of the cyclo-dodeka-depsipeptide valinomycin, modification of the sequence of the amino acids to lysin-valinomycin and derivatizations for fluorescence investigations. Diploma thesis, K.-F.-University of Graz, 1997.

20 Balcom, B. J., Petersen, N. O. Solvent dependence of carboxylic acid condensations with dicyclohexylcarbodiimide. J. Org. Chem. 1989, 54, 1922-1927.

21 Nakanishi, S., Butler, K. Synthesis of chlorocarbonyl ketenes. Org. Prep. Proc. Int. 1975, 7, 155 158.

22 Kappe, Th. A synthesis of 2-hydroxyquinolizinones-(4). Monatsh. Chem. 1967, 98, 874-886.

23 Ziegler, E., Junek, H., Rossmann, U. About fused heterocycles. Monatsh. Chem. 1961, 92, 809813.

24 Stadlbauer, W., Fiala, W., Fischer, M., Hojas, G. Thermal cyclization of 3-acyl-4-azidopyridines to isoxazolo[4,3-c]pyridines. J. Prakt. Chem. - Chem. Ztg. 2000, 342, 33-39.

25 Underwood, H. W. Jr., Gale, J. C. The preparation of derivatives for the identification of alkyl chlorides. J. Amer. Chem. Soc. 1934, 56, 2117-2120.

Sample Availability: Available from the authors.

(C) 2001 by MDPI (http://www.mdpi.org). Reproduction is permitted for noncommercial purposes 